\begin{abstract}
Iranica
Abstracta Iranica Revue bibliographique pour le domaine irano-aryen

Volume 32-33 | 2013

Comptes rendus des publications de 2009-2010
\end{abstract}

\title{
Ken Parry (ed.). The Blackwell Companion to Eastern Christianity
}

Florence Jullien

\section{OpenEdition}

1 Journals

\section{Édition électronique}

URL : http://journals.openedition.org/abstractairanica/40877

DOI : 10.4000/abstractairanica.40877

ISSN : 1961-960X

Éditeur :

CNRS (UMR 7528 Mondes iraniens et indiens), Éditions de l'IFRI

\section{Édition imprimée}

Date de publication : 1 décembre 2013

ISSN : 0240-8910

\section{Référence électronique}

Florence Jullien, « Ken Parry (ed.). The Blackwell Companion to Eastern Christianity », Abstracta Iranica [En ligne], Volume 32-33 | 2013, document 343, mis en ligne le 01 juillet 2016, consulté le 26

septembre 2020. URL : http://journals.openedition.org/abstractairanica/40877 ; DOI : https://doi.org/ 10.4000/abstractairanica.40877

Ce document a été généré automatiquement le 26 septembre 2020.

Tous droits réservés 


\title{
Ken Parry (ed.). The Blackwell Companion to Eastern Christianity
}

\author{
Florence Jullien
}

\section{RÉFÉRENCE}

Ken Parry (ed.). The Blackwell Companion to Eastern Christianity. Oxford, John Wiley and Sons Ltd, 2010, 528 p. (The Blackwell Companions to Religion)

1 Ce compendium met à la portée du public cultivé et averti une synthèse des données sur l'histoire religieuse et politique des Églises chrétiennes orientales jusqu'à nos jours. Il inclut aussi bien les Églises slaves (bulgare, roumaine, russe, serbe) que byzantine ou les christianismes orientaux copte, éthiopien, arménien, caucasien, syriaque, etc. Les communautés de diaspora sont également évoquées, ainsi que les traditions, l'hagiographie et la sociologie catholiques et orthodoxes en des chapitres spécifiques. Ce Companion répond bien à la vocation de la collection: synthèse et diffusion des connaissances.

\section{AUTEURS}

FLORENCE JULLIEN

EPHE, Paris 